\title{
The Opportunity of SMEs Development by Triple Helix ABG Method in Supporting Creative Economy in Pangkalpinang City
}

\author{
Hamsani and Khairiyansyah \\ Department of Management, Faculty of Economics, University of Bangka Belitung \\ hamsani@ubb.ac.id
}

\begin{abstract}
Creative industries based on local wisdom are born from the creativity of the community who see the potential and unique characteristics in its region. Pangkalpinang City is the capital of the province of Bangka Belitung Islands always strives to improve economic development in improving the level of welfare of its people, one of them through the creation of SMEs. This study aims to identify and analyze how SMEs development opportunities by Tripple Helix ABG method in supporting creative economy in Pangkalpinang City. Kind of this research is descriptive qualitative approach by data collecting. This study is one of Small Research and Development $(R$ \& D) category. Respondents of this research are the beginner perpetrator of SMEs Creative Industry in Pangkalpinang City. The SMEs' men are 61 persons. In this research, creative economy field covers 9 (nine) sectors: Advertising, Publishing and Printing, Fashion, Design, Research and Development, Information Technology, Architecture, Craft, and Interactive Games. The results of this study indicate the efforts and roles of each aspect of Triple Helix have not been so maximal, so further development opportunities can still be done.
\end{abstract}

Keywords: SMEs, Creative Economy, Triple Helix ABG

\section{Introduction}

The creative industries developed in Indonesia are based on GDP, employment, as well as corporate and international trade activities. In 2009-2014, Indonesia's creative industry is targeted to contribute between 7-8\%. Its GDP growth is calculated based on GDP growth that has been targeted by the government and also the target of creative industry GDP contribution to national GDP. Until now the GDP growth trend in creative industry sub-sector is $2.7 \%$ for architecture; $2.4 \%$ for design; $2.6 \%$ for fashion; $5.9 \%$ for film, video and photography; $5.5 \%$ for handicrafts; $12.5 \%$ for computer and software services; $0.6 \%$ for music; $-3.9 \%$ for market and art goods; $-0.2 \%$ for publishing and printing; $12 \%$ for advertising; $14.9 \%$ for interactive games; $7.2 \%$ for research and development; $6.6 \%$ for performing arts; and 6\% for television and radio.

Developing Creative Industry Based on Local Wisdom Through According to Desperindag in blueprint printed 12009 "Creative Industries Development of 2025" mentions that the main problem which becomes the focus of creative industry development plan to 2015 is the quality and quantity of humanity of creative industry, business climate, technology, business networks and capital. Capital is not the main problem to stimulate the development of this creative industry but the most important is how the creative industry players can add soft skills that support their business, technology, and information related to the industry. In an effort to overcome the problems to develop creative industry in Indonesia can not only depend on government efforts and programs only but there must be support from various parties such as 
economic institutions, academics, business people, and society. Creative industries based on local wisdom are born from the creativity of the community who see the potential and unique characteristics if a product in association with local wisdom in the area. Pangkalpinang City is the capital of the province of Bangka Belitung Islands always strives to increase economic development in improving the welfare level of its people. Various efforts to improve the welfare of the community through the development and empowerment of SMEs in Pangkalpinang city.

\section{Literature Reviews}

\section{Definition of SMEs}

In Indonesia, there are different definitions of SMEs based on the institutional interests that define them:

a. Central Bureau of Statistics (BPS): SME is a company or industry with workers between 5-19 people.

b. Bank Indonesia (BI): SME is a company or industry with the following characteristics: (a) its capital is less than Rp. 20 million; (b) for one round of his effort requires only Rp 5 juts; (c) having a maximum asset of Rp 600 million outside land and buildings, and (d) annual turnover $\leq \mathrm{Rp} 1$ billion.

c. Ministry of Cooperatives and Small and Medium Enterprises (UU No. 9/1995): SMEs are small and traditional economic activities of the people, with a net worth of RP 50 million - Rp. 200 Million (excluding land and building of business place) and annual turnover $\leq$ Rp 1 billion; in the UMKM / 2008 law with a net worth of Rp 50 million to Rp 500 million and annual net sales of $\mathrm{Rp} 300$ million to $\mathrm{Rp} 2.5$ billion.

d. Keppres No. 16/ 1994: SMEs are companies with a maximum net worth of Rp. 400 million.

e. Ministry of Industry and Trade: 1) The Company has maximum assets of Rp 600 million outside land and building (Ministry of Industry before merged), 2) The Company has working capital below Rp 25 million.

f. Ministry of Finance: SMEs are companies that have a maximum turnover of Rp 600 million per year and or a maximum asset of Rp 600 million outside land and buildings.

g. Ministry of Health: companies that have quality standard marking in the form of Certificate of Extension (SP), Domestic Brand (MD) and Foreign Brand (ML).

\section{Definition of Triple Helix}

This creative economic enterprise cannot develop by itself. "It" requires the touch of three stakeholders known as the triple helix, ie businessmen, intellectuals, and government in a holistic, concrete and sustainable networking.

\section{Definition of the Creative Economy}

The term creative economy began to be known globally since the advent of The How to Make Money From Ideas (2011) by John Howkins. Howkins concisely defines the Creative Economy as: "The Creation of Value as a Result Ideas". Howkins more clearly defines the creative economy as an economic activity in which input and output are ideas. Or in one short sentence, the essence of creativity is the idea. In other cases Howkins explains that creative economy is an 
economic activity in a society that spends most of its time generating ideas, not just doing routine and repetitive things.

\section{Definition of the Creative Industry}

According to DCMS (Creative Digital Industries National Mapping Project ARC Center of Excellent for Creative Industries and Innovation, 2007) creative industry is an industry derived from the utilization of creativity, skills and individual talents to create welfare and employment through the creation and utilization of creativity and creativity such individuals (NAF / WRT / 001 / I / 2009 January issue). The same thing was also expressed by Mohammad Adam Jerusalem (2009), that the creative industry is an industry that has authenticity in individual creativity, skills and talents that have the potential to generate income and job creation through the exploitation of intellectual property.

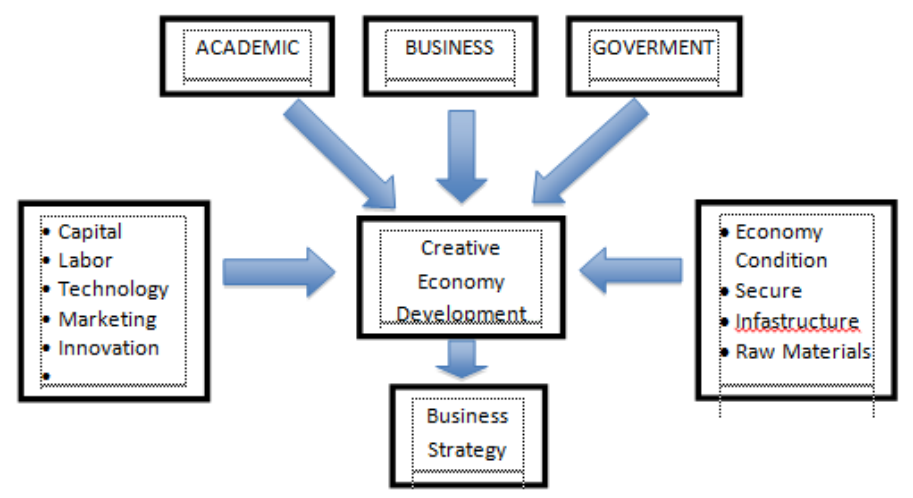

Figure 1. Research Framework

\section{Research Purposes}

To analyze and know how SMEs development opportunities through Tripple Helix ABG method in supporting the creative economy in Pangkalpinang City.

\section{Benefits of Research}

A. Practical Benefits

1. Providing inputs for SMEs to be able to expand their business through Tripple Helix ABG Method in supporting creative economy in Pangkalpinang City.

2. Providing inputs to local governments that there is a need for greater support in SME development in Pangkalpinang City.

B. Theoretical Benefits

Application in SME development and empowerment strategy.

\section{Research Methods}

\section{Type of Research}

The approach taken in this research is the qualitative descriptive approach to data collection in the field. This study belongs to the category of Small Research and Development (R \& D). On the aspect of the research will be revealed the profile of SMEs in the city of Pangkalpinang, 
mapping potential creative industry players, and needs analysis through Triple Helix ABG approach.

\section{Time and Place of Study}

The time of the research is conducted for 1 year, starting from January 2014 until December 2014. The place of research implementation is to SME creative industry players in Pangkalpinang city.

\section{Data Collection Technique}

Data collection techniques, both primary and secondary data are done by:
a. Interview
The interview is collecting data obtained through questionnaire and answer with SME Creative Industry players in Pangkalpinang city.
b. Field Research
Undertake the process of introduction to the object of research that includes activities at the location of SMEs Creative Industries
c. Library Study and previous studies.
Techniques of collecting data sought the basics of thought through books, information,

\section{Population and Sample}

Population and Sample in this research are SMEs Creative industry Beginner category in Pangkalpinang City, with 9 sectors of study are: Advertising, Publishing and Printing, Craft, Design, Fashion, Technology and Information, Interactive Game, Research and Development, Architecture.

\section{Data Analysis Technique}

Because the data are related to behavioral exposure and statements and perceptions, the data are generally qualitative data, while some data in the form of numbers or quantitative will be used to complement and assist the descriptions of qualitative data.

\section{Results}

Recapitulation of interview result:

Table 1. Interview Results 61 Respondents - Yes/No Questions

\begin{tabular}{|c|c|c|c|}
\hline NO & YES $(\boldsymbol{\%})$ & NO $(\boldsymbol{\%})$ & MAJORITY \\
\hline 1 & 60 & 40 & YES \\
\hline 2 & 40 & 60 & NO \\
\hline 3 & 20 & 80 & NO \\
\hline 4 & 40 & 60 & NO \\
\hline 6 & 70 & 30 & YES \\
\hline 7 & 60 & 40 & YES \\
\hline 8 & 80 & 20 & YES \\
\hline
\end{tabular}


IJBE: Integrated Journal of Business and Economics

e-ISSN: 2549-3280

\begin{tabular}{|c|c|c|c|}
\hline 9 & 80 & 20 & YES \\
\hline 11 & 70 & 30 & YES \\
\hline 12 & 60 & 40 & YES \\
\hline 13 & 30 & 70 & NO \\
\hline 14 & 80 & 20 & YES \\
\hline
\end{tabular}

Source: Data processed by researchers, 2014.

Based on the above table can be obtained data as follows:

1. Most respondents answered that the universities (PT) have visited and do observation in their place of business.

2. Most respondents answered that the PT never provided assistance and guidance to their business.

3. Most respondents replied that the PT was never involved in the operationalization of their business.

4. Most respondents answered that the PT has never given advocacy and consultancy related to capital, technology, human resources, or managerial in their business.

5. Most respondents answered that the level of competition in their business is quite high.

6. Most respondents answered that their business also depends on other types of business.

7. Most respondents replied that their business has good prospects.

8. Most respondents answered that their business contributed to the growth of creative industries.

9. Most respondents replied that the Government of Pangkalpinang City (Related Office) had visited and made observations to their place of business.

10. Most respondents replied that the Government of Pangkalpinang City (Related Office) once provided assistance and guidance to their business.

11. Most respondents answered that the relevant Dinas never made policies that complicate the operationalization of their businesses.

12. Most respondents replied that the relevant Dinas provided formal training on capital, technology, human resources, or managerial in their business.

\section{The interview results are based on questions with explanations}

Based on the results of interviews on respondents, obtained information as follows:

1. Respondents gave their opinion that what can be done by universities to support the growth of creative industry are:

a. Participate and do their business assistance

b. Synergize with the government to provide counseling and training for their businesses

c. Can contribute to the facilitation of creative industries supporting equipment

d. Facilitate apprenticeship programs for students to assist their businesses

2. Respondents argue that what their business can do to support the creative industry is:

a. Improve their business performance with the achievement of profit that continues to grow with positive progress

b. As inspiring business for follower development for similar business

c. Continue to grow up to support the tourism sector as a superior sector alternative

3. Respondents argued that the Pangkalpinang City Government to support the growth of the creative industries could do the following: 
a. Strengthening government functions as mediators and regulators to enhance the growth of creative industries.

b. To facilitate socialization to strengthen market share and coverage of creative industries marketing area.

c. Facilitating the training of SMEs in the creative industry sector must be targeted and appropriate benefits.

d. The Government may provide incentives or capital access facilities for the development of creative industries in Pangkalpinang.

\section{Urgency of Creative Industry Development in Pangkalpinang City}

Here are some items that explain how the creative industry has a crucial role for the development of several aspects of life:

1. Aspects of economic contribution: creating employment, creating prosperity of the people of Pangkalpinang City.

2. Business aspects: creating markets for other industries and supporting other business sectors in Pangkalpinang City.

3. Social impact: improving Human Development Index (HDI) and quality of life of the people of Pangkalpinang City.

4. Identity: cultural heritage, build culture, keep the values that have been crystallized to the people of Pangkalpinang City.

5. Innovation and Creativity: improving innovation, helping problem solving, and stimulating creativity of the people of Pangkalpinang City.

6. Communication: strengthen ideas and ideas, as a discussion forum, and the outlook on the people of Pangkalpinang City.

\section{Creative Industry Development Opportunity in Pangkalpinang City}

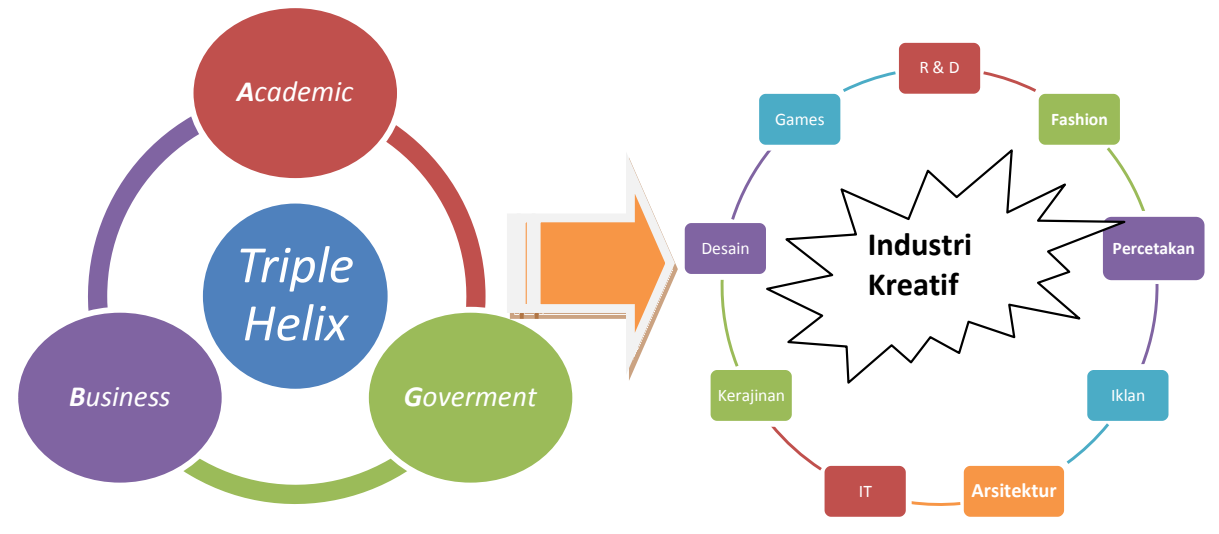

Source: primary data processed, 2014

\section{Figure 2. Scheme of Development of 9 Creative Industries Sector in Pangkalpinang}

From the schematic above picture can be explained the process of strengthening the development of 9 creative industry sectors in Pangkalpinang can be pursued through Triple Helix method, with detail explanation as follows: 
1. From the Academic dimension, the efforts that can be done to strengthen the development of creative industries include business assistance, counselling and training, equipment facilitation, student internship program.

2. From the Business dimension, efforts that can be done is to improve business performance, as a model (inspiring business), and support other business sectors

3. From the Government dimension, the strengthening of activities that can be done in strengthening the function of mediator and regulator, facilitation of marketing, training, as well as government incentives and easy access to capital.

\section{Conclusions and Recommendations}

\section{Conclusions}

Based on the explanation and discussion and the previous analysis can be concluded several things as follows:

1. Efforts and synergy of academic, business, and government in developing creative industry in Pangkalpinang felt not maximal yet.

2. Each Triple Helix dimension has a function and role in the development of Creative Industry in Pangkalpinang

3. The creative industry is a crucial entity in improving the quality of life in some aspects of life.

4. The existence of opportunities and gap efforts that still felt necessary to improve the creative industry sector in Pangkalpinang.

\section{Recommendations}

1. The synergy of ABG needs to be continuously improved for the purpose of improving the quality of Creative Industry in Pangkalpinang.

2. Any development opportunities suggested by respondents for the development of Creative Industry need to get special attention from Pangkalpinang City Government.

3. One sector of Creative Industry such as craft should be a vehicle that can inherit and strengthen the culture and values and norms prevailing in the community of Pangkalpinang City.

\section{References}

Departemen Perdagangan Republik Indonesia. (2008). Pengembangan Ekonomi Kreatif Indonesia 2025: Rencana Pengembangan Ekonomi Kreatif Indonesia 2009-202.

Etzkowitz, H. and Leydesdorff, L. (2000). The Dynamics of Innovation: From National Systems and 'Mode 2' to a Tripple Helix of University-Industry Government. Research Policy 29.

Ginanjar, S. (2010). Analisis Pengaruh Inovasi Produk Melalui Kinerja Pemasaran Untuk Mencapai Keunggulan Bersaing Berkelanjutan (Studi Kasus Pada Industri Kecil danMenengah Batik Pekalongan). Jurnal Fakultas Ekonomi Magister Manajemen UNDIP Semarang. 
Kementrian Koperasi dan UKM. (2010). Renstra (RencanaStrategis) Kementrian Koperasi dan UKM Tahun 2010 - 2014. Jakarta.

Kuncoro, M. (2003). Metode Riset untuk Bisnis dan Ekonomi. Jakarta: Penerbit Erlangga.

Kuncoro, M. (2004). Otonomi \& Pembangunan Daerah: Reformasi, Perencanaan, Strategi dan Peluang. Jakarta: Erlangga.

Muniarti, D. E. (2009). Peran Perguruan Tinggi Dalam Tripple Helix Sebagai Upaya Pengembangan Industri Kreatif'. Seminar Nasional Jurusan PTBB FT UNY.

Purnama. dkk. (2003). Analisis Pengaruh Sumber-sumber Keunggulan Bersaing Bidang Pemasaran Terhadap Kinerja Perusahaan Manufaktur Di Indonesia. Jurnal Siasat Bisnis, (2)8.

Sukarno, G. (2013). Pertumbuhan Industri Kreatif Di Surabaya Melalui Upaya Triple Helix Dan Keunggulan Bersaing. Seminar Nasional \& Sidang Pleno ISEI XVI.

Sukarno. dkk. (2012). Competitive Advantage Throught "SANTRI" Community In Improving Performance, GLOBAL NETWORK. International Journal of Business Management, (5)2.

Tambunan, T. (2000), Perkembangan Industri Skala Kecil di Indonesia, Jakarta: PT Mutiara Sumber Widya.

Tambunan, T. (2003). Perkembangan UKM dalam Era AFTA: Peluang, Tantangan, Permasalahan dan Alternatif Solusinya. Paper Diskusi pada Yayasan Indonesia Forum 